\title{
Research Article \\ INVESTIGATING RELATIONSHIP BETWEEN ATTRIBUTES, JOB PERFORMANCE AND JOB SATISFACTION OF RURAL AGRICULTURE EXTENSION OFFICERS IN UJJAIN DISTRICT OF MADHYA PRADESH
}

\author{
SAXENA A.K. AND SHARMA CHANDRIKA* \\ Department of Extension Education, College of Agriculture, Ganj Basoda, 464221, Jawaharlal Nehru Krishi Vishwa Vidyalaya, Adhartal, Jabalpur, 482004, Madhya \\ Pradesh \\ ${ }^{*}$ Corresponding Author: Email-chandrikasharma1991@gmail.com
}

Received:February 01, 2018; Revised: February 12, 2018; Accepted: February 13, 2018; Published: February 15, 2018

\begin{abstract}
The study has been conducted by the KVK Ujjain with 72 respondents to know the attributes of Rural Agriculture Extension Officers (RAEOs), job performance, job satisfaction and training needs of RAEOs. Correlation between attributes, job performance and job satisfaction of RAEOs has also been worked along with the involvement of RAEOs in other work than transfer of technology. The major findings were as majority of respondents belongs to $46-50$ years of age group, had higher secondary to post graduation level of education and possess 25-29 years of work experience. Most of them performed both related and allotted work, change work according to instructions from the authority and work as per instructions of the department. Regarding job satisfaction, majority of them were satisfied with allotted and transfer of technology work and were highly satisfied in perception during the field work among the farmer community. Education was found negatively correlated with job satisfaction and had positive correlation with job performance. Age and experience were positively correlated with job satisfaction and negatively correlated with job performance. Among training needs of RAEOs priorities were given to rainfed production technique and organic farming by the RAEOs. Hundred per cent of the respondents agreed on their involvement in election work/photo identity work among the works other than transfer of technology.
\end{abstract}

Keywords- Age group, Correlation, Education, Job performance, Job satisfaction, RAEOs, Transfer of technology.

Citation: Saxena A.K. and Sharma Chandrika (2018) Investigating Relationship between Attributes, Job Performance and Job Satisfaction of Rural Agriculture Extension Officers in Ujjain District of Madhya Pradesh. International Journal of Agriculture Sciences, ISSN: 0975-3710 \& E-ISSN: 0975-9107, Volume 10, Issue 3, pp.-5127-5128. DOl: http://dx.doi.org/10.9735/0975-3710.10.3.5127-5128

Copyright: Copyright@2018 Saxena A.K. and Sharma Chandrika. This is an open-access article distributed under the terms of the Creative Commons Attribution License, which permits unrestricted use, distribution and reproduction in any medium, provided the original author and source are credited.

Academic Editor / Reviewer: Dr Avtar Singh Bimbraw, Aparna Jaiswal, Aradhana Kumari

\section{Introduction}

In the early fifties, the need for specific agencies to implement rural development programs in India was recognized and a new administrative unit; development blocks were established as a primary administrative unit headed by a Block Development Officer (BDO), created to assist the departmental dealing with agriculture, horticulture, cooperatives, animal husbandry, village industries etc. the staffing pattern included a number of Assistant Development Officers (ADOs) and Village Level Workers (VLWs), the latter were assigned specific sub-units, normally consisting of a few villages. Being workers of multipurpose nature, it was stipulated that VLWs would spend 75 per cent of their time on functions related to the promotion of improved agricultural practices. Over a period of time, the activities of different development department increased many folds, as did the work of the VLWs. In addition, the VLWs came to be increasingly deployed in activities not connected with agriculture, such as elections, census, family planning etc., which reduced the time devoted to agricultural programmes. Not only this, under the reorganized set up of extension system, the entire responsibility of transfer of technology rests upon the shoulder of Rural Agriculture Extension Officers (RAEOs), previously designated as VLWs. Hence, they should have up-to-date knowledge of all latest developments made in the fields of agriculture along with the keen interest and convincing the farmers for using the latest farm technology.

It is not possible for the specialists of agriculture alone to do all jobs effectively, unless they are given proper training in all the concerned branches. The term 'job' means a set of expectations applied to an incumbent of a position and 'job- performance' is the actual behavior of the incumbent [1]. The performance of an individual at work in an organization depends on his personal qualities and the environment where he works. It is quite logical to expect that those who are satisfied with their job are likely to perform their job in a better way and communication behavior is also positively and significantly related with job performance [2]. In this background, the present study was undertaken with following objectives:

1. To study selected attributes of RAEOs.

2. To assess the job performance and job satisfaction of RAEOs.

3. To study the relationship between selected attributes, job performance and job satisfaction of the RAEOs.

4. To know the training needs and the involvement of RAEOs in tasks other than transfer of technology work.

\section{Materials and Methods}

The present study was conducted by the Krishi Vigyan Kendra Ujjain in the Ujjain district of Madhya Pradesh. The district has six blocks and seven tehsils and a total of 127 RAEOs are deployed at six blocks of the district. Out of these 72 respondents were randomly selected during the in-service training programme at KVK. The data were collected by personal interview, observations, group interview and discussion with KVK functionaries. The collected data were scored, classified, analyzed and presented in the form of percentage in the tables. Correlation of coefficient was employed to calculate the relation between attributes, job performance and job satisfaction of RAEOs. 


\section{Results and Discussion \\ Attributes of respondents}

\begin{tabular}{|c|c|c|c|}
\hline \multicolumn{4}{|c|}{ Table-1 Demographic distribution of respondent } \\
\hline $\begin{array}{l}\text { S. } \\
\text { No. }\end{array}$ & $\begin{array}{c}\text { Attributes I } \\
\text { Independent variables }\end{array}$ & $\begin{array}{l}\text { Respondents } \\
\quad(N=72)\end{array}$ & $\%$ \\
\hline \multicolumn{4}{|c|}{ Age } \\
\hline 1. & $30-35$ years & 02 & 02.77 \\
\hline 2. & $36-40$ years & 04 & 05.55 \\
\hline 3. & $41-45$ years & 18 & 25.00 \\
\hline 4. & $46-50$ years & 48 & 66.66 \\
\hline \multicolumn{4}{|c|}{ Education } \\
\hline 1. & Higher secondary & 24 & 33.33 \\
\hline 2. & B.Sc. (Ag.) & 02 & 02.77 \\
\hline 3. & Graduate (non-B.Sc. Ag.) & 22 & 30.55 \\
\hline 4. & $\begin{array}{l}\text { Post graduates (non- } \\
\text { M.Sc. Ag.) }\end{array}$ & 24 & 33.33 \\
\hline \multicolumn{4}{|c|}{ Experience } \\
\hline 1. & $10-14$ years & 10 & 13.88 \\
\hline 2. & $15-19$ years & 02 & 02.77 \\
\hline 3. & $20-24$ years & 18 & 25.00 \\
\hline 4. & $25-29$ years & 42 & 58.33 \\
\hline
\end{tabular}

[Table-1] reveals that majority of respondents belonged to above 45 years of age $(66.66 \%)$ while $02.77 \%$ were young (30-35 years) followed by middle age group $(25.00 \%)$ having educational qualification of higher secondary level to post graduate (non-M.Sc. Ag. ). Only $02.77 \%$ respondents were agriculture graduates.

\section{Job Performance}

Table-2 Distribution of respondents according to their job performance

\begin{tabular}{|c|l|c|c|}
\hline $\begin{array}{c}\text { S. } \\
\text { No. }\end{array}$ & \multicolumn{1}{|c|}{ Job performance } & $\begin{array}{c}\text { Respondents } \\
(\mathrm{N}=72)\end{array}$ & $\begin{array}{c}\text { Percentage } \\
(\%)\end{array}$ \\
\hline \multicolumn{4}{|c|}{ Working pattern } \\
\hline 1. & All related work & 12 & 16.66 \\
\hline 2. & Only allotted work & 02 & 02.77 \\
\hline 3. & Both & 58 & 80.55 \\
\hline \multicolumn{4}{|c|}{ Plan of work } \\
\hline 1. & Pre planning & 27.77 \\
\hline 2. & $\begin{array}{l}\text { Change the working pattern } \\
\text { as per need of the farmers }\end{array}$ & 22 & 30.55 \\
\hline 3. & $\begin{array}{l}\text { Change the working } \\
\text { according to instructions } \\
\text { from authority }\end{array}$ & 32 & 44.44 \\
\hline \multicolumn{4}{|c|}{ Type/system of work } \\
\hline 1. & $\begin{array}{l}\text { As per instructions of the } \\
\text { Department }\end{array}$ & 54 & 75.00 \\
\hline 2. & As per need of the farmers & 12 & 16.66 \\
\hline 3. & To achieve the target & 06 & 08.33 \\
\hline
\end{tabular}

Job performance has been measured through involving working pattern, plan of work and type/system of work of the respondents. It is clear from the [Table-2] that a huge majority (80.55\%) of the respondents performed both allotted and related works followed by all related work (16.66\%). The $44.44 \%$ of respondents replied that they prepare their plan of work on the basis of instructions from the authority and $30.55 \%$ declared that they change their work as per need of the farmers, while $27.77 \%$ of respondents work as pre planned. It is also found that in case of system of work, majority of the respondents $(75.00 \%)$ work as per instructions of the department, whereas $16.66 \%$ work as per need of the farmers and only $08.33 \%$ work to achieve the target.

\section{Job Satisfaction}

Table-3 Distribution of respondents according to their job satisfaction
\begin{tabular}{|c|l|c|c|}
\hline $\begin{array}{c}\text { S. } \\
\text { No. }\end{array}$ & Job satisfaction & Respondents (N=72) & $\begin{array}{c}\text { Percentage } \\
(\%)\end{array}$ \\
\hline \multicolumn{4}{|c|}{ Allotted work } \\
\hline 1. & Highly satisfied & 10 & 13.88 \\
\hline 2. & Satisfied & 48 & 66.66 \\
\hline 3. & Dissatisfied & 08 & 12.00 \\
\hline 4. & Neutral & 06 & 09.00 \\
\hline \multicolumn{4}{|c|}{ Transfer of new technologies among the farmers } \\
\hline 1. & Highly satisfied & 10 & 13.88 \\
\hline 2. & Satisfied & 60 & 83.33 \\
\hline 3. & Dissatisfied & 02 & 02.77 \\
\hline 4. & Neutral & 00 & 00.00 \\
\hline \multicolumn{4}{|c|}{ Perception during the field work among the farmer community } \\
\hline 1. & Highly satisfied & 24 & 33.33 \\
\hline 2. & Satisfied & 21 & 29.10 \\
\hline 3. & Dissatisfied & 07 & 09.72 \\
\hline 4. & Neutral & 20 & 27.77 \\
\hline
\end{tabular}

Allotted work, transfer of new technologies among the farmers and perception during the field work among the farmer community were measured to know the job satisfaction of the RAEOs. [Table-3] shows that majority (66.66\%) respondents were satisfied with their allotted work followed by $13.88 \%$ highly satisfied while only $12.00 \%$ expressed dissatisfaction towards their allotted work and $09.00 \%$ had neutral feeling about their allotted work. In case of transfer of new technology among the farmers, the majority of respondents (83.33\%) expressed satisfaction and $13.88 \%$ showed high satisfaction whereas only $02.77 \%$ expressed dissatisfaction. Regarding perception of RAEOs during field work among the farmer community, majority (33.33\%) of respondents were highly satisfied, $29.10 \%$ were satisfied and $27.77 \%$ had neutral feeling. However, $09.72 \%$ of respondents were dissatisfied with the perception during the field work among the farmers [3].

\section{Relationship between selected attributes, job performance and job} satisfaction of the RAEOs

Table-4 Coefficient of correlation between selected attributes, job performance and job satisfaction of RAEOs.

\begin{tabular}{|c|l|c|c|}
\hline S. No. & Attributes & Job performance & Job satisfaction \\
\hline 1. & Education & $0.76175^{* *}$ & $-0.0971^{\mathrm{NS}}$ \\
\hline 2. & Age & $-0.169687^{\mathrm{NS}}$ & $0.511^{\text {** }}$ \\
\hline 3. & Experience & $-0.207623^{\mathrm{NS}}$ & $0.542^{* *}$ \\
\hline \multicolumn{4}{|c}{${ }^{* *}$ Significant } \\
\hline
\end{tabular}

[Table-4] indicates that the age and working experience had negative correlation whereas education had positive correlation with job performance. Hence, it can be stated that age and work experience does not affect working pattern, plan of work and type of work of RAEOs. It is also observed that age and experience had positive and significant correlation with job satisfaction while education had negative correlation. Hence, it can be concluded that respondents with higher level of educational qualification like post graduate were not related to job satisfaction whereas age and work experience had positive relation.

\section{Training needs of the RAEOs}

Table-5 Distribution of respondents according to their training needs

\begin{tabular}{|c|l|c|c|c|}
\hline $\begin{array}{c}\text { S. } \\
\text { No. }\end{array}$ & \multicolumn{1}{|c|}{ Subject } & $\mathrm{N}=72$ & $\%$ & Rank \\
\hline 1. & Rainfed production techniques & 68 & 94.44 & I \\
\hline 2. & Use of micro-nutrients & 52 & 72.22 & $\mathrm{IV}$ \\
\hline 3. & Use of Bacillus thuringiensis based insecticide & 38 & 52.77 & $\mathrm{VII}$ \\
\hline 4. & Methodology of insecticide & 42 & 58.33 & $\mathrm{VI}$ \\
\hline 5. & IPM & 48 & 66.66 & $\mathrm{~V}$ \\
\hline 6. & Seed storage & 53 & 73.61 & $\mathrm{III}$ \\
\hline 7. & Organic farming & 61 & 84.72 & $\mathrm{II}$ \\
\hline 8. & Causes of vegetable growth & 23 & 31.94 & $\mathrm{VIII}$ \\
\hline 9. & Proper time of weedicides application & 21 & 29.16 & $\mathrm{IX}$ \\
\hline 10. & $\begin{array}{l}\text { Critical stages of various crop prone to affect } \\
\text { productivity due to biotic and abiotic stresses. }\end{array}$ & 20 & 27.77 & $\mathrm{X}$ \\
\hline
\end{tabular}


It can be noted from the [Table-5] that majority of the RAEOs (94.44\%) expressed priority in obtaining trainings on rainfed production technology followed by organic farming $(84.72 \%)$, seed storage $(73.61 \%)$, use of micro-nutrients $(72.22 \%)$, IPM $(66.66 \%)$, methodology of insecticide $(58.33 \%)$ and use of Bacillus thuringiensis based insecticide $(52.77 \%)$. While about 30 per cent of the respondents expressed their training needs on causes of vegetable growth, proper time of weedicides application and critical stages of various crops prone to affect productivity due to biotic and abiotic stresses [4]. The reported findings suggest that RAEOs needs additional training in technical areas.

\section{Involvement of RAEOs in tasks other than transfer of technology work}

Table-6 Distribution of respondents according to their involvement in other than transfer of technology work

\begin{tabular}{|c|l|c|c|}
\hline $\begin{array}{c}\text { S. } \\
\text { No. }\end{array}$ & \multicolumn{1}{|c|}{ Other work } & N=72 & $\%$ \\
\hline 1. & Election work/photo identity work & 72 & 100.00 \\
\hline 2. & $\begin{array}{l}\text { National programmes- pulse polio, plantation \& water } \\
\text { conservation }\end{array}$ & 38 & 52.00 \\
\hline 3. & PBL \& BPL survey & 42 & 58.33 \\
\hline 4. & Public distribution scheme & 38 & 52.77 \\
\hline 5. & Prime Ministers, rozgar scheme work & 22 & 30.55 \\
\hline 6. & Counting of animals & 27 & 37.50 \\
\hline 7. & Formation of SHGs & 10 & 13.88 \\
\hline 8. & Conduction of gram sabha & 34 & 47.22 \\
\hline 9. & Nodal officer at panchayat level & 36 & 50.00 \\
\hline 10. & Janpad (block) panchayat work & 58 & 80.55 \\
\hline 11. & Input distribution & 70 & 97.2 \\
\hline 12. & $\begin{array}{l}\text { Survey work of contingent plan (frost attack \& insect } \\
\text { pest infestation) }\end{array}$ & 68 & 94.44 \\
\hline
\end{tabular}

Hundred per cent of the respondents stated that they are being deployed in election related work while $97.22 \%$ respondents clearly stated that they were involved in input distribution work assigned by their department. On the contrary, the least involvement was seen in the interventions, which could lead to a stable source of income generation through group approach (SHG formation, 13.88\%).

\section{Conclusion}

Findings of the study indicates that respondents were satisfied with their allotted work and respondents with higher level of education like post graduation were not related to job satisfaction. The study strongly indicates that age of respondents and the work experience had a positive bearing on the level of satisfaction. Majority of the respondents over 45 years of age and 25 years of work experience were highly satisfied with their job. The fact cannot be denied that the human is characterized by the ever-lasting desire of changes. They may be for the better or for the worst but it is the essence of change that really matters. Like everything agricultural trends are unpredictably changing and it is additional proof of this passion of mankind. According to the study, the RAEOs from different age groups, experiences and qualification believe in how important it is to be in line with the latest. To increase the participation of farmers in KVK activities, majority of the RAEOs completed their job and performed as social worker in the field. But involvement of RAEOs in other work than transfer of technology (TOT) activities has lead to sufferings in the field as they are the most effective medium of expansion of technology.

\section{Application of research}

The study is helpful in improving the job performance and job satisfaction of extension functionaries through providing ideas to the planning committees. Hence, would help in framing better policies and schemes for extension personnel development and strengthening the extension channel.

\section{Research Category: Agriculture Extension}

IPM- Integrated Pest Management

KVK- Krishi Vigyan Kendra

ADO-Agriculture Development Officer

VLW- Village Level Worker

BDO- Block Development Officer

$\mathrm{N}$ - total number of respondents

$\%$ - percentage

Acknowledgement: Author are thankful to College of Agriculture, Ganj Basoda, 464221, Jawaharlal Nehru Krishi Vishwa Vidyalaya, Adhartal, Jabalpur, 482004, Madhya Pradesh. Also, thanks to Krishi Vigyan Kendra, Ujjain, Madhya Pradesh 455001 for providing support and response to carry out the research

\section{*Principle Investigator: Dr A K Saxena}

University: Rajmata Vijayaraje Scindia Krishi Vishwavidyalaya, Gwalior, Madhya Pradesh 474002

Research project name or number: NIL

Author Contributions: All author equally contributed

Author statement: All authors read, reviewed, agree and approved the final manuscript

\section{Conflict of Interest: None declared}

Ethical approval: This article does not contain any studies with human participants or animals performed by any of the authors.

\section{References}

[1] Mishra P.K., Jaiswal D.K. and Mishra Anupam (1988) Maharashtra Journal of Extension Education, (7), 89-91.

[2] Reddy M., Srinivasulu and Jayaramaiah K.M. (1988) Indian Journal of Extension Education, (24), 34-38.

[3] Das S. and Laharia S.N. (2003) Job satisfaction of gram root level agricultural extension functionaries in West Bengal. 1st National Extension Education Congress, 69.

[4] Saxena A.K. and Thakur P. (1997) Maharashtra Journal of Exension Education, (14), 197.

[5] Bhatia B.S. and Sandhu A.S. (1975) Indian Journal of Extension Education, 11(1\&2), 62-24.

[6] Kashem K.J.B. and Mthumpa D.M. (2003) South African Journal Of Agriculture Extension, (26), 12-30.

[7] Prasad S.V., Reddy B.L. and Shivarayana S. (2000) Journal of Research ANGRAU, 31(1), 105-107. 